\title{
Premature delivery and cannabinoid receptor expression in the placenta after delivery: an observational study.
}

\author{
Stepan Feduniw ${ }^{1}$, Izabela Woś $^{2}$, Katarzyna Pogoda ${ }^{2}$, Piotr Laudanski ${ }^{3}$, Jacek \\ Tabarkiewicz $^{2}$, and Grzegorz Raba ${ }^{2}$ \\ ${ }^{1}$ Lazarski University \\ ${ }^{2}$ University of Rzeszów \\ ${ }^{3}$ Medical University of Warsaw
}

December 1, 2020

\begin{abstract}
Objective: To investigate the relationship between cannabinoid receptor expression within the placenta after delivery and the problem of preterm delivery. Design, setting, and participants: The retrospective, observational study was conducted on a multicenter material of 150 women. The study group included 115 women after premature delivery. The control group consisted of 35 women after term delivery. Methods. To determine the expression of cannabinoid receptors after the end of the third stage of labour, several sections were taken from the placenta. RNA isolation, reverse transcription, and Real-Time PCR were performed to assess the expression of the cannabinoid receptors in the placenta. Results: Cannabinoid receptor type 2 expression was lower in the placentas of women after preterm delivery. Urinary tract infections and bleeding at any stage of pregnancy occurred statistically more frequently in the study group and correlated with cannabinoid receptor type 2 expression. In the study group, the history of preterm labor, history of intrauterine fetal deaths, pregnancies terminated by a Caesarean section, and uterine tenderness correlated with lower expression of cannabinoid receptor type 2 and 1 a. Conclusions: Cannabinoid receptors mRNA were present in human placental tissue during pregnancy. Decreased cannabinoid receptor type 2 expression in preterm delivered placentas should be further investigated, as perinatal endocannabinoid receptor expression could serve as a predicting tool of preterm birth. For example, liquid-based cytology could be used as a noninvasive perinatal method of measuring the expression level of cannabinoid receptors in decidual cells during pregnancy. KEYWORDS: Cannabinoid receptor; CB2; endocannabinoid system; preterm delivery; PTB
\end{abstract}

\section{Introduction}

Preterm delivery is a persisting problem of modern neonatal medicine. Despite the continued development of neonatal support, due to the frequent occurrence of preterm birth (PTB), neonatal outcomes are still unsatisfactory $^{1}$. PTB occurs in 5-9\% in Europe, $12-14 \%$ in the United States, and around $18 \%$ in Africa and $\mathrm{Asia}^{2}$; it leads to critical medical conditions of the fetuses, the psychological distress of the parents, and significant economic losses as each of these newborns require exceptional medical support.

Preterm babies are vulnerable because of the high incidence of respiratory distress (93\% of infants), retinopathy of prematurity (59\%), patent ductus arteriosus (46\%), bronchopulmonary dysplasia (42\%), late-onset sepsis $(36 \%)$, necrotizing enterocolitis (11\%), grade III or higher (7-9\%) intraventricular hemorrhage, periventricular leukomalacia (3\%), according to a report from the Eunice Kennedy Shriver National Institute of Child Health and Human Development Neonatal Research Network on very low birth weight (less than 1500 $\mathrm{g})^{3}$.

There are several hypotheses on why PTB occurs. The factors which seem to play a role include preterm hypothalamic-pituitary-adrenal axis stimulation connected with a stress reaction, preterm placental abrup- 
tion, pathological uterine expansion, and resulting preterm rupture of the membranes, as well as an inflammatory response in the urogenital tract ${ }^{4,5}$.

The inflammatory effect is one of the mechanisms of PTB and term delivery. A higher concentration of the inflammatory cytokines was found in the amniotic fluid after delivery ${ }^{6,7}$. Raba et al., in their study, observed that inflammatory cytokines played a crucial role in over $80 \%$ of PTB cases, especially in deliveries before $30 . \mathrm{hbd}^{8}$. Preterm prelabour rupture of the membranes might also be caused by an infection of the amniotic sac. Vagina's bacterial flora plays an important role, as the presence of Ureaplasma urealyticum, Mycoplasma hominis, and Chlamydia trachomatis predisposes to $\mathrm{PTB}^{9,10}$.

The endocannabinoid signaling system (ECS) includes the endocannabinoid receptor type 1 (CB1) and type 2 (CB2) as well as endogenous ligand (arachidonoylethanolamide and 2-arachidonoyl glycerol) for the cannabinoid receptors ${ }^{11}$. Low levels of anandamide help support the pregnancy, however, if its level becomes too high, it can lead to miscarriages ${ }^{12}$. One of the best-known exogenous activators of CB1 and CB2 is $\Delta 9$ tetrahydrocannabinol (THC), found in Cannabis sativa (marijuana), which is often used as a psychoactive agent ${ }^{13}$. Signaling pathways mediated by the cannabinoid receptors (CB) may affect cell proliferation, differentiation, and apoptosis in animal and human cells ${ }^{14,15}$.

CB1 is encoded by the CNR1 gene and is found mainly in the central nervous system and the heart, liver, uterus, testes, and the small intestine ${ }^{16,17}$. CB1 receptor also has alternative splice variant forms endocannabinoid receptor type 1a (CB1a) and endocannabinoid receptor type $1 \mathrm{~b}(\mathrm{CB} 1 \mathrm{~b})$. Both isoforms are encoded by the gene CNR1 and are found in the brain, similarly to CB1 $1^{18,19}$. The CB2, encoded by CNR2 is expressed in T and B lymphocytes as well as macrophages and hematopoietic cells, brain, and other peripheral tissues, where it modulates the immune response ${ }^{16,17}$.

$\mathrm{CB}$ is involved in both male and female reproductive systems ${ }^{13}$. In the female reproductive system, the CB receptors are located in the oviduct, uterus, embryo ${ }^{14}$. ECS plays a significant role in oogenesis regulation, embryo development, embryo transport, implantation, and placental development. ECS is also involved in the maintenance of pregnancy and in childbirth ${ }^{14}$. Many studies show that the ECS affects pregnancy outcomes, but the precise role of the endocannabinoid receptor is still unknown.

The objective of the study was the investigation of the relationship between the expression of the cannabinoid receptors within the placenta after delivery and the problem of preterm delivery.

\section{Materials and methods}

The study was conducted on a multicenter material of placental probes from the Obstetrics Department of the Provincial Hospital of Przemyśl, Department of Perinatology of the Medical University Bialystok, and Obstetrics Clinic of the Medical University of Lublin. Using CinCalc.com sample size calculator the minimal sample size was established on 34 women $^{20}$. The material was taken from 150 women who gave birth in the period from March 2004 to December 2012. 115 women were diagnosed with premature delivery and were included in the Study Group, 35 women had a delivery at term and were allocated to the Control Group.

The following inclusion criteria were used: spontaneous deliveries concluded with vaginal delivery or with an emergency Cesarean section between 22. gestational weeks and 36. gestational weeks and 6 days. The control group consisted of women who had a spontaneous delivery between 37 gestational weeks and 40 gestational weeks and 6 days were included. Patients with diagnosed complications during the current pregnancy, as multiple gestations, anemia, intrahepatic cholestasis of pregnancy, acute fatty liver of pregnancy, chronic kidney disease, autoimmune disorders, immunodeficiency, group of placentae previa, fetal growth restriction, oligohydramnios, polyhydramnios and other rare complications not otherwise described were excluded from the study. Fetal chromosomal abnormalities, fetuses with diagnosed anatomical abnormalities during the current pregnancy, pregnancies conceived using in vitro fertilization, and intrauterine fetal demise were also excluded from the study.

This study was in accordance with the STROBE Statement - Checklist of items of cohort studies, which can be found in the appendix of the study ${ }^{21}$. 
Every patient was informed about the aim of the study, its process, and agreed to it before the involvement in the study. The study had received the approbation of the Bioethical Committee of the University of Rzeszów (Nr. 05/10/2020).

\section{Placental samples}

Placental tissue samples were collected directly after the third stage of labour. Samples were taken from four, unaffected parts of the placenta, one from each quadrant. The tissue was placed in a tube and stored at $-80^{\circ} \mathrm{C}$ until the analysis. CB expression was compared to reference proteins glyceraldehyde 3-phosphate dehydrogenase and $\beta$-actin. RNA isolation, then reverse transcription, and finally, Real-Time PCR was conducted to calculate the expression of the mRNA of the examined genes.

\section{RNA isolation}

Total RNA was isolated from placental tissue with the use of Gene MATRIX Universal RNA Purification Kit (EurX, Gdansk, Poland) supplemented with TRI-reagent (phenol equilibrated, stabilized: chloroform: isoamyl alcohol 25:24:1) (AppliChem GmbH, Darmstadt, Germany) and $\beta$-mercaptoethanol (Acros Organics, New Jersey, USA). The procedure was conducted according to the manufacturer's protocol. $3 \mathrm{mg}$ of each sample were homogenized using gentleMACS Tubes (Miltenyi Biotec GmbH, Bergisch Gladbach, Germany) and gentleMACS Dissociator (Miltenyi Biotec GmbH, Bergisch Gladbach, Germany). Total RNA quantity and concentration were measured by Nanodrop 2000 spectrophotometer (Thermofisher Scientific, Massachusetts, USA) and stored at $-80^{\circ} \mathrm{C}$.

\section{Reverse transcription}

RNA extraction was followed by gDNA elimination and reverse transcription performed using QuantiTect Reverse Transcription Kit (Qiagen, Hilden, Germany). $1 \mu \mathrm{g}$ of RNA was transcribed. All reactions were prepared on ice. Incubations during the reverse transcription procedure were conducted in Labcycler 48 (SensoQuest GmbH, Göttingen, Germany). Obtained cDNA was stored at $-80^{\circ} \mathrm{C}$ temperature.

\section{Real-Time PCR}

Real-Time PCR procedure was carried out in thermal cycler Roche LightCycler@ 480 Real-Time PCR System (Roche Diagnostics Ltd, Basel, Switzerland) with the use of Power-Up SYBR Green Master Mix (Applied Biosystems, California, USA). The target genes in our study wereCNR1, CNR1a, and CNR2 encoding CB1, CB1a, and CB2, respectively. The reference genes in the procedure were ACTB ( $\beta$-actin) and GAPDH (glyceraldehyde 3-phosphate dehydrogenase). In a single reaction, we used $1 \mu \mathrm{l}$ of cDNA. Gene-specific primers were used at a $10 \mu \mathrm{M}$ concentration (Table 1).

Table 1. Primers' sequences

\begin{tabular}{|c|c|}
\hline Target gene & Primers' sequences (5'-3') \\
\hline$\overline{A C T B}$ & $\begin{array}{l}\text { F: 5'-CTGGAACGGTGAAGGTGACA-3' R: } \\
\text { 5'-GTAACAACGCATCTCATATTTGGAA-3' }\end{array}$ \\
\hline$G A P D H$ & $\begin{array}{l}\text { F: 5'-AGAAGGCTGGGGCTCATTTG-3' R: } \\
\text { 5'-TGATGGCATGGACTGTGGTCAT-3' }\end{array}$ \\
\hline$C N R 1$ & $\begin{array}{l}\text { F: 5'-TCATTAAGACGGTGTTTGCATTCT-3' R: } \\
\text { 5'-CGTGTCGCAGGTCCTTACTC-3' }\end{array}$ \\
\hline CNR1a & $\begin{array}{l}\text { F: 5'-TGCAGAGCTCTCCGTAGTCA-3' R: } \\
\text { 5'-TGGTCCTCGGGACAGAAG-3' }\end{array}$ \\
\hline CNR2 & $\begin{array}{l}\text { F: 5'-TCATCTACACCTATGGGCATGTTCT-3' } \\
\text { R: 5'-CCTCATTCGGGCCATTCC-3' }\end{array}$ \\
\hline
\end{tabular}

The Real-Time PCR procedure was preceded by standard curve preparation. The Real-Time PCR programs consisted of the Uracil-DNA glycosylase activation step at $50^{\circ} \mathrm{C}$ for $2 \mathrm{~min}$, initial denaturation at $95^{\circ} \mathrm{C}$ for 
2 min followed by 45 cycles of denaturation at $95^{\circ} \mathrm{C}$ for $15 \mathrm{sec}$ and annealing at $60^{\circ} \mathrm{C}$ for $1 \mathrm{~min}$. The last step was the melting curve performed to ensure reaction specificity. Specific expression levels were calculated using the $1 /[?] \mathrm{Ct}$ algorithm, where $\Delta \mathrm{Ct}$ is the $\mathrm{Ct}$ value of the target splicing variant minus the mean of $\mathrm{Ct}$ value of reference genes.

\section{Statistical analysis}

All statistical analyses were performed using StatSoft, Inc. STATISTICA (data analysis software system), 13.3 version, and the significant values were assessed for p-value [?] 0.05.

\section{Results}

There were not statistically or clinically significant differences between the study and the control groups. The characteristics of the analysed population are presented in Table 2.

The average expression of the CB2 was significantly lower in the study group than in the control group, 26,8 vs. 31,1 ( $(\mathrm{p}=0.038)$, respectively. There were more placentas without CB2 expression in the study group, 23 vs. 3, respectively. Moreover, CB2 expression correlated with the occurrence of PTB $(\mathrm{p}=0.038)$, what was shown in the Figure 1. Table 4 shows the correlation between PTB risk factors and the level of receptors. Expression of the receptors in the study and control group were shown in the Table 3.

\section{Discussion}

\section{Main findings}

This study seems to be the first report on the expression of CB during human pregnancy. This study found the link between the expression of CB receptors and PTB in analysed postpartum placentas. First of all, endocannabinoid receptors were present in the placental tissue after delivery. Moreover, PTB correlated with lower CB2 expression in the placentas and was significantly lower than in term births. This could result from a few mechanisms of $\mathrm{CB}$ action, namely its two main effects: influence on muscular tissue and engagement in the inflammatory process.

\section{Interpretation}

Raba and Tabarkiewicz showed that the level of cytokines influence PTB. Moreover, an algorithm based on the measurement of selected cytokines' concentration might help predict $\mathrm{PTB}^{22}$. Multiple studies describe CB2 modulating influence the release of the cytokines ${ }^{23-26}$. Moreover, $\mathrm{CB}$ can be stimulated a number of cytokines (IL-1, IL-4, IL-10, IL-6, TNF-a, IL-8, MIP-1(CCL3 and CCL4), RANTES(CCL5)) ${ }^{23,27-30}$. Further studies are needed to establish the exact correlation between cytokines and CB2 stimulation in pregnant women. The endocannabinoid system modulates the action of leukocytes by stimulating the CB2 presented on leukocyte cells ${ }^{31}$, which in turn inhibits the inflammatory response ${ }^{32}$. This observation was also made intrauterine in patients with adenomyosis ${ }^{33,34}$. PTB might be associated with inflammation caused by intraamniotic infection ${ }^{35}$, but inflammation as an origin of physiological delivery takes place without infection $^{4,32}$. Inflammation could be initiated by a decrease in the expression of CB2 in the placenta, leading to a complete loss of the receptors ${ }^{26}$. Stimulation of the CB2 during pregnancy could be responsible for pregnancy tolerance ${ }^{36}$. However, further studies are needed to confirm this hypothesis.

There was a positive correlation between the tenderness of the uterus before labour and CB1 and CB1a expression. This symptom could be associated with worsened contractions of the uterus. In earlier studies, the stimulation of the $\mathrm{CB}$ receptor led to the relaxation of the skeletal muscles ${ }^{37,38}$, smooth muscles of blood vessels ${ }^{39}$, and uterine smooth muscles ${ }^{40}$. Therefore, the stimulation of the $\mathrm{CB}$ receptors in the uterus was described as tocolysis ${ }^{41}$. As a result, a decrease in level of the receptors could lead to preterm uterine contractions and PTB. CB1 and CB1a expression was not connected with PTB. Nevertheless, in the study group, lower CB1 and CB1a expression correlated with higher uterine pain. This correlation could be caused by the generally increased pain feeling of the patients. Stimulating the peripheral CB receptors could lead to an antipoint effect without central, psychoactive action ${ }^{42-44}$, also in the uterus ${ }^{34}$. There are no studies describing supervised usage and the influence of selective CB modulators in pregnant women. However, 
retrospective studies of exogenous cannabinoid usage confirmed a rising percentage of adverse pregnancy outcomes ${ }^{45-47}$. What if there were selective CB stimulators without harmful effects? They could be used to relieve patients' pain without the psychoactive influence of the cannabinoids. The potential role of CB2 expression in human myometrium in the development of the placenta, uterus, and thus in childbirth, was demonstrated by Dennedy ${ }^{40}$. Further studies gave information about an important role of anandamide in supporting pregnancy, including in placental hormonal activities and its development ${ }^{48,49}$. Studies also suggest that testing for anandamide levels may be one methods used to predict $\mathrm{PTB}^{50}$.

In the human model, there are studies on CB expression in the endometrium in patients with endometriosis due to the inflammatory process ${ }^{33,34,51-53}$, and as an inflammatory response to endometrial cancer ${ }^{54}$.

Earlier studies in animal models reported similar results. Sun et al. observed that a lower expression of the CNR2 gene correlated with PTB in mice ${ }^{55}$. Another study also showed that decreased CB2 and increased CB1 expression are associated with PTB. In this study, PTB appeared due to preterm induction with lipopolysaccharide ${ }^{32}$. Wang et al. showed that decreased CB1 expression in the placenta of mice correlated with $\mathrm{PTB}^{56}$.

In earlier studies, there are only a few reports about the connection of $\mathrm{CB}$ expression and risk factors of the PTB. Increased CB1 protein level has been shown in women with a spontaneous miscarriage, furthermore higher CB1 protein levels were observed in preeclamptic placental tissue ${ }^{57}$. Therefore, it seems that a decrease in CB1 and CB1a mRNA level could be connected with, for example, preterm placental abruption, which leads to delivery of the immature fetuses or intrauterine death of the fetus ${ }^{58}$. We have not observed similar effects in our study as no observation of intrapartum CB mRNA levels was performed. Nevertheless, low CB1 and CB1a levels correlated with a history of intrauterine death of the fetus. In the current study, a significant correlation was observed between bleeding in the early stages of the pregnancy with lower CB2 expression. Vaginal bleeding in late pregnancy is the most common early symptom of placental abruption ${ }^{59}$. Bleeding in the first trimester is a known PTB risk factor ${ }^{60,61}$. Thus, bleeding can be interpreted as a risk of preterm delivery because of extremely early placental abruption. This raises another question - what if the lowering of $\mathrm{CB}$ is responsible for extremely preterm $(<22 \mathrm{hbd})$ delivery in the mechanism of placental abruption, presenting as an intrauterine death of the fetus or miscarriage?

\section{Strengths and Limitations}

The correlation between CB expression and PTB observed in this study could be used in clinical practice. Further studies should be performed to assess the expression of CB receptors during pregnancy. Knowledge about perinatal receptor expression could lead to improved PTB prediction. This tool could improve neonatal outcomes connected with prematurity. Amniocentesis or chorionic villus sampling could be used to examine intrauterine CB level. Moreover, liquid-based cytology could be used as a noninvasive perinatal method of measuring the expression level of $\mathrm{CB}$ in decidual cells during pregnancy. However, further researches seem necessary to verify this thesis,

\section{Conclusions and Implications}

The expression of CB1, CB1a, CB2 mRNA was found to be present in human placental tissue during pregnancy. The finding that there is lower CB2 expression in PTB placentas is a crucial step which might, in further investigations, lead to the development of a prediction model of PTB. The correlation between CB1, CB1a, CB2 expression and pregnancy complications found in this study, such as history of preterm delivery, history of intrauterine death of the fetus, vaginal bleeding during pregnancy, increased body temperature during delivery, and urinary tract infections, shows that the assessment of cannabinoid receptor expression in pregnant women at various stages of pregnancy should be performed. Further studies are needed to assess the expression of CB during pregnancy. Knowledge about perinatal receptor expression could lead to improved PTB prediction. Liquid-based cytology could be used as a noninvasive perinatal method of measuring the expression level of CB in decidual cells during pregnancy.

\section{Abbreviations:}


Average value (A)

$\beta$-actin (ACTB)

Body mass index (BMI)

Cannabinoid receptors $(\mathrm{CB})$

Cannabinoid receptor type 1 (CB1)

Cannabinoid receptor type 1 alpha (CB1a)

Cannabinoid receptor type 2 (CB2)

Cannabinoid receptor type 1 gene (CNR1)

Cannabinoid receptor type 1 alpha gene (CNR1a)

Cannabinoid receptor type 2 gene (CNR2)

C-reactive protein (CRP)

$\Delta^{9}$-tetrahydrocannabinol (THC)

Endocannabinoid system (ECS)

Fetal heart rate (FHR)

Gestational week (hbd)

Glyceraldehyde 3-phosphate dehydrogenase (GAPDH)

Preterm birth (PTB)

Reference gene (REF)

Standard deviation (SD)

\section{Contribution and Authorship}

SF and IW have equal contributions to the study. SF, IW, JT, KP and GR conceived the original idea and coordinated the study. SF, IW, JT, and GR contributed with the data collection. SF performed the statistical analysis. All the authors contributed to the interpretation of the results. SF and IW took the lead in writing the manuscript with the support of PL, JT and GR. SF contributed to the acquisition and organization during the review process. All the authors critically reviewed and contributed to the final version of the manuscript.

\section{Details of Ethics Approval}

This article is protected by copyright. All rights reserved

The study had received the approbation of the Bioethical Committee of the University of Rzeszów (reference number. 05/10/2020). Procedures were in concordance with the Declaration of Helsinki. Every patient was informed about the aim of the study, its process, and agreed to it before the involvement in the study.

\section{Conflict of interest}

Nothing to declare.

\section{Funding and Acknowledgments}

The study was performed within the project Centre for Innovative Research in Medical and Natural Sciences realized by the University of Rzeszow, co-financed within the Regional Operational Programme for the Podkarpackie Province for the years 2007-2013, contract number UDA-RPPK.01.03.00-18-004/12-00. 


\section{References}

1. Steer P. The epidemiology of preterm labour. BJOG: An International Journal of Obstetrics and Gynaecology. 2005;112(SUPPL. 1):1-3.

2. Goldenberg RL, Culhane JF, Iams JD, Romero R. Epidemiology and causes of preterm birth. The Lancet. 2008 Jan 5;371(9606):75-84.

3. Stoll BJ, Hansen NI, Bell EF, Shankaran S, Laptook AR, Walsh MC, et al. Neonatal outcomes of extremely preterm infants from the NICHD Neonatal Research Network. Pediatrics. 2010;126(3):443-56.

4. Raba G, Kotarski J. Evaluation of risk factors can help to predict preterm delivery within 7 days in women hospitalized for threatened preterm labour. Journal of Maternal-Fetal and Neonatal Medicine. 2016 Oct $1 ; 29(19): 3142-6$.

5. Royal College of Obstetricians and Gynaecologists R. Preterm Labour, Antibiotics, and Cerebral Palsy. Royal College of Obstetricians and Gynaecologists. 2013;(33):1-8.

6. Melekoglu R, Yilmaz E, Ciftci O, Kafadar YT, Celik E. Associations between second-trimester amniotic fluid levels of ADAMTS4, ADAMTS5, IL-6, and TNF- $\alpha$ and spontaneous preterm delivery in singleton pregnancies. Journal of Perinatal Medicine. 2019 Apr 1;47(3):304-10.

7. Houben ML, Nikkels PGJ, van Bleek GM, Visser GHA, Rovers MM, Kessel H, et al. The association between intrauterine inflammation and spontaneous vaginal delivery at term: A cross-sectional study. PLoS ONE. 2009 Aug 10;4(8).

8. Raba G. Ocena czynników ryzyka i wybranych markerów biochemicznych w predykcji porodu przedwczesnego. Rozprawa na stopień naukowy doktora habilitowanego. Przemyśl: F.U.H. TIM GRAFIK; 2011. $205 \mathrm{p}$.

9. Krymko H, Bashiri A, Smolin A, Sheiner E, Bar-David J, Shoham-Vardi I, et al. Risk factors for recurrent preterm delivery. European Journal of Obstetrics and Gynecology and Reproductive Biology. 2004;113(2):160-3.

10. Lamont RF, Taylor-Robinson D, Wigglesworth JS, Furr PM, Evans RT, Elder MG. The role of mycoplasmas, ureaplasmas and chlamydiae in the genital tract of women presenting in spontaneous early preterm labour. Journal of Medical Microbiology. 1987;24(3):253-7.

11. Correa F, Wolfson ML, Valchi P, Aisemberg J, Franchi AM. Endocannabinoid system and pregnancy. Vol. 152, Reproduction. BioScientifica Ltd.; 2016. p. R191-200.

12. Shao Z, Yin J, Chapman K, Grzemska M, Clark L, Wang J, et al. High-resolution crystal structure of the human CB1 cannabinoid receptor. Nature. 2016 Dec 22;540(7634):602-6.

13. Innocenzi E, De Domenico E, Ciccarone F, Zampieri M, Rossi G, Cicconi R, et al. Paternal activation of CB2 cannabinoid receptor impairs placental and embryonic growth via an epigenetic mechanism. Scientific Reports. 2019;9(1):1-13.

14. Fügedi G, Molnár M, Rigó J, Schönléber J, Kovalszky I, Molvarec A. Increased placental expression of cannabinoid receptor 1 in preeclampsia: An observational study. BMC Pregnancy and Childbirth. 2014 Dec $2 ; 14(1): 395$.

15. Pyszniak M, Pogoda K, Mazur A, Tabarkiewicz J, Zakład KI, Klinicznej I. The role of Endocannabinoid System in pathogenesis and therapy of obesity. Endokrynologia Pediatryczna. 2014;2(47):65-76.

16. Sun X, Cappelletti M, Li Y, Karp CL, Divanovic S, Dey SK. Cnr2 deficiency confers resistance to inflammation- induced preterm birth in mice. Endocrinology. 2014 Oct 1;155(10):4006-14. 
17. Helliwell RJA, Chamley LW, Blake-Palmer K, Mitchell MD, Wu J, Kearn CS, et al. Characterization of the endocannabinoid system in early human pregnancy. Journal of Clinical Endocrinology and Metabolism. 2004 Oct;89(10):5168-74.

18. Bagher AM, Laprairie RB, Kelly MEM, Denovan-Wright EM. Co-expression of the human cannabinoid receptor coding region splice variants (hCB1) affects the function of hCB1 receptor complexes. European Journal of Pharmacology. 2013 Dec 5;721(1-3):341-54.

19. Console-Bram L, Marcu J, Abood ME. Cannabinoid receptors: Nomenclature and pharmacological principles. Vol. 38, Progress in Neuro-Psychopharmacology and Biological Psychiatry. Prog Neuropsychopharmacol Biol Psychiatry; 2012. p. 4-15.

20. Sample Size Calculator [Internet]. [cited 2020 Apr 11]. Available from: https://clincalc.com/stats/samplesize.aspx

21. Ramke J, Palagyi A, Jordan V, Petkovic J, Gilbert CE. Using the STROBE statement to assess reporting in blindness prevalence surveys in low and middle income countries. PLOS ONE. 2017 May 8;12(5):e0176178.

22. Raba G, Tabarkiewicz J. Cytokines in preterm delivery: Proposal of a new diagnostic algorithm. Journal of Immunology Research. 2018;2018.

23. Silver RJ. The Endocannabinoid System of Animals. Animals. 2019;9(9):686.

24. Fechtner S, Singh AK, Srivastava I, Szlenk CT, Muench TR, Natesan S, et al. Cannabinoid receptor 2 agonist JWH-015 inhibits interleukin-1ßinduced inflammation in rheumatoid arthritis synovial fibroblasts and in adjuvant induced arthritis rat via glucocorticoid receptor. Frontiers in Immunology. 2019;10(MAY):1027.

25. Kapellos TS, Taylor L, Feuerborn A, Valaris S, Hussain MT, Rainger GE, et al. Cannabinoid receptor 2 deficiency exacerbates inflammation and neutrophil recruitment. FASEB Journal. 2019 May 1;33(5):615467.

26. Liu YJ, Fan HB, Jin Y, Ren CG, Jia XE, Wang L, et al. Cannabinoid receptor 2 suppresses leukocyte inflammatory migration by modulating the JNK/c-Jun/Alox5 pathway. Journal of Biological Chemistry. 2013;288(19):13551-62.

27. Klein TW, Lane B, Newton CA, Friedman H. The cannabinoid system and cytokine network (44546). Experimental Biology and Medicine. 2000;225(1):1-8.

28. Hua T, Vemuri K, Pu M, Qu L, Han GW, Wu Y, et al. Crystal Structure of the Human Cannabinoid Receptor CB1. Cell. 2016 Oct 20;167(3):750-762.e14.

29. Xing C, Zhuang Y, Xu TH, Feng Z, Zhou XE, Chen M, et al. Cryo-EM Structure of the Human Cannabinoid Receptor CB2-Gi Signaling Complex. Cell. 2020;180(4):645-654.e13.

30. Li X, Hua T, Vemuri K, Ho JH, Wu Y, Wu L, et al. Crystal Structure of the Human Cannabinoid Receptor CB2. Cell. 2019 Jan 24;176(3):459-467.e13.

31. Sun X, Deng W, Li Y, Tang S, Leishman E, Bradshaw HB, et al. Sustained endocannabinoid signaling compromises decidual function and promotes inflammation-induced preterm birth. Journal of Biological Chemistry. 2016 Apr 8;291(15):8231-40.

32. Bariani MV, Rubio APD, Cella M, Burdet J, Franchi AM, Aisemberg J. Role of the endocannabinoid system in the mechanisms involved in the LPS-induced preterm labor. Reproduction. 2015;150(6):463-72.

33. Shen X, Duan H, Wang S, Hong W, Wang YY, Lin SL. Expression of Cannabinoid Receptors in Myometrium and its Correlation With Dysmenorrhea in Adenomyosis. Reproductive Sciences. $2019 ; 26(12): 1618-25$.

34. Bilgic E, Meydanli EG, Kose S, Aydin MC, Karaismailoglu E, Akar I, et al. Endocannabinoids modulate apoptosis in endometriosis and adenomyosis. Acta Histochemica. 2017;119(5):523-32. 
35. Drews K, Pieńkowski W. Intraamniotic infection - still more questions than answers. Ginekologia i Perinatologia Praktyczna. 2016;1(4):141-51.

36. Taylor AH, Amoako AA, Bambang K, Karasu T, Gebeh A, Lam PMW, et al. Endocannabinoids and pregnancy. Vol. 411, Clinica Chimica Acta. Elsevier; 2010. p. 921-30.

37. Baldassano S, Serio R, Mule' F. Cannabinoid CB1 receptor activation modulates spontaneous contractile activity in mouse ileal longitudinal muscle. European Journal of Pharmacology. 2008 Mar 17;582(1-3):132-8.

38. Lipina C, Stretton C, Hastings S, Hundal JS, Mackie K, Irving AJ, et al. Regulation of MAP kinasedirected mitogenic and protein kinase B-mediated signaling by cannabinoid receptor type 1 in skeletal muscle cells. Diabetes. 2010 Feb;59(2):375-85.

39. Romano MR, Lograno MD. Cannabinoid agonists induce relaxation in the bovine ophthalmic artery: Evidences for CB 1 receptors, nitric oxide and potassium channels. British Journal of Pharmacology. 2006;147(8):917-25.

40. Dennedy MC, Friel AM, Houlihan DD, Broderick VM, Smith T, Morrison JJ. Cannabinoids and the human uterus during pregnancy. American Journal of Obstetrics and Gynecology. 2004;190(1):2-9.

41. Asghari-Roodsari A, Lesani A, Javadi-Paydar M, Tabatabaeefar L, Tavangar SM, Norouzi A, et al. Tocolytic effect of $\Delta 9$-tetrahydrocannabinol in mice model of lipopolysaccharide-induced preterm delivery: Role of nitric oxide. Reproductive Sciences. 2010 Apr;17(4):391-400.

42. Woodhams SG, Sagar DR, Burston JJ, Chapman V. The role of the endocannabinoid system in pain. Handbook of Experimental Pharmacology. 2015;227:119-43.

43. Thapa D, Cairns EA, Szczesniak AM, Kulkarni PM, Straiker AJ, Thakur GA, et al. Allosteric cannabinoid receptor 1 (CB1) ligands reduce ocular pain and inflammation. Molecules. 2020;25(2):11-3.

44. Malan TP, Ibrahim MM, Vanderah TW, Makriyannis A, Porreca F. Inhibition of pain responses by activation of CB2 cannabinoid receptors. Chemistry and Physics of Lipids. 2002;121(1-2):191-200.

45. Metz TD, Allshouse AA, Hogue CJ, Goldenberg RL, Dudley DJ, Varner MW, et al. Maternal marijuana use, adverse pregnancy outcomes, and neonatal morbidity. American Journal of Obstetrics and Gynecology. 2017 Oct 1;217(4):478.e1-478.e8.

46. Chang X, Bian Y, He Q, Yao J, Zhu J, Wu J, et al. Suppression of STAT3 Signaling by $\Delta 9$ Tetrahydrocannabinol (THC) Induces Trophoblast Dysfunction. Cellular Physiology and Biochemistry. 2017 Jul 1;42(2):537-50.

47. Natale B V., Gustin KN, Lee K, Holloway AC, Laviolette SR, Natale DRC, et al. $\Delta 9$ Tetrahydrocannabinol Exposure During Rat Pregnancy Leads To Symmetrical Fetal Growth Restriction and Labyrinth-Specific Vascular Defects in the Placenta. Scientific Reports. 2020;10(1):1-15.

48. Nallendran V, Lam P, Marczylo T, Bankart M, Taylor A, Taylor D, et al. The plasma levels of the endocannabinoid, anandamide, increase with the induction of labour. BJOG: An International Journal of Obstetrics and Gynaecology. 2010 Jun 20;117(7):863-9.

49. Cella M, Leguizamón GF, Sordelli MS, Cervini M, Guadagnoli T, Ribeiro ML, et al. Dual Effect of Anandamide on Rat Placenta Nitric Oxide Synthesis. Placenta. 2008 Aug;29(8):699-707.

50. Bachkangi P, Taylor AH, Bari M, Maccarrone M, Konje JC. Prediction of preterm labour from a single blood test: The role of the endocannabinoid system in predicting preterm birth in high-risk women. European Journal of Obstetrics and Gynecology and Reproductive Biology. 2019 Dec 1;243:1-6.

51. Brighton PJ, McDonald J, Taylor AH, Challiss RAJ, Lambert DG, Konje JC, et al. Characterization of anandamide-stimulated cannabinoid receptor signaling in human ULTR myometrial smooth muscle cells. Molecular Endocrinology. 2009 Sep;23(9):1415-27. 
52. Taylor AH, Abbas MS, Habiba MA, Konje JC. Histomorphometric evaluation of cannabinoid receptor and anandamide modulating enzyme expression in the human endometrium through the menstrual cycle. Histochemistry and Cell Biology. 2010;133(5):557-65.

53. Tanaka K, Mayne L, Khalil A, Baartz D, Eriksson L, Mortlock SA, et al. The role of the endocannabinoid system in aetiopathogenesis of endometriosis: A potential therapeutic target. European Journal of Obstetrics and Gynecology and Reproductive Biology. 2020;244:87-94.

54. Maia J, Fonseca BM, Teixeira N, Correia-Da-Silva G. The fundamental role of the endocannabinoid system in endometrium and placenta: Implications in pathophysiological aspects of uterine and pregnancy disorders. Human Reproduction Update. 2020 Jun 18;26(4):586-602.

55. Sun X, Cappelletti M, Li Y, Karp CL, Divanovic S, Dey SK. Cnr2 deficiency confers resistance to inflammation- induced preterm birth in mice. Endocrinology. 2014;155(10):4006-14.

56. Wang H, Xie H, Dey SK. Loss of cannabinoid receptor CB1 induces preterm birth. PLoS ONE. 2008;3(10):e3320.

57. Trabucco E, Acone G, Marenna A, Pierantoni R, Cacciola G, Chioccarelli T, et al. Endocannabinoid System in First Trimester Placenta: Low FAAH and High CB1 Expression Characterize Spontaneous Miscarriage. Placenta. 2009 Jun;30(6):516-22.

58. Malacova E, Tippaya S, Bailey HD, Chai K, Farrant BM, Gebremedhin AT, et al. Stillbirth risk prediction using machine learning for a large cohort of births from Western Australia, 1980-2015. Scientific reports. 2020 Dec 1;10(1):5354.

59. Erez O, Novack L, Klaitman V, Erez-Weiss I, Beer-Weisel R, Dukler D, et al. Early preterm delivery due to placenta previa is an independent risk factor for a subsequent spontaneous preterm birth. BMC Pregnancy and Childbirth. 2012;12(1):1.

60. Hossain R, Harris T, Lohsoonthorn V, Williams MA. Risk of preterm delivery in relation to vaginal bleeding in early pregnancy. European Journal of Obstetrics and Gynecology and Reproductive Biology. 2007;135(2):158-63.

61. Hackney DN, Glantz JC. Vaginal bleeding in early pregnancy and preterm birth: Systemic review and analysis of heterogeneity. Journal of Maternal-Fetal and Neonatal Medicine. 2011 Jun;24(6):778-86.

\section{Hosted file}

Figure 1.pdf available at https://authorea.com/users/380437/articles/496429-prematuredelivery-and-cannabinoid-receptor-expression-in-the-placenta-after-delivery-anobservational-study

\section{Hosted file}

Tables.pdf available at https ://authorea.com/users/380437/articles/496429-premature-deliveryand-cannabinoid-receptor-expression-in-the-placenta-after-delivery-an-observationalstudy 